\title{
航走波の推定計算法の比較について
}

塩 谷 茂 明*

\section{On Comparison of Estimation Methods of Ship Waves}

\author{
Shigeaki SHIOTANI
}

\begin{abstract}
The waves generated by a small vessel traveling freely in a coastal sea area cause severe sea conditions for marine small floating bodies. Therefore, it is very important to research the characteristics of the ship waves by a small vessel and the motions of a small floating body in her waves, and to estimate these ship waves and their motions.

This paper deals with the comparison of the numerical estimation and two kinds of simplified calculation method of ship-generated waves developed in my previous work. These calculated results are also compared with the experimental data in the real sea area. The characteristics of ship waves by these calculation methods are obtained.
\end{abstract}

\section{1.はじめに}

航行船舶による航走波は数個の大波高の波群とし て伝搬する。その時、航走波は比較的静穞な海域に 忽然と出現し、遊泳者がその到来に気づかずに波に 淩われたり、遊漁船から釣り客の海中落下等の危険 性を伴うことがある。また、状況次第で航走波が操 業中の小型船舶の転覆や海洋浮体構造物の損傷等の 海難発生の要因となることもある。特に、最近小型 船舶の高速化に伴い、大波高の航走波を生成しなが ら疾走する船舶が多く見られ、このような危険度が 高くなることが危惧され、航走波の予測や波高抑制 のための航行規制対策等、航走波に関する研究は今 後極めて重要になるものと考之られる。

著者らは各種小型船舶が造る航走波の計測実験を 実船で行い、航走波の諸特性について調查し た(1)(2)(3)。さらに、二種類の航走波の簡易式予測法に ついて諭し、実験結果との比較から航走波の推定に ついて検討した。これら一連の研究から、簡易式航 走波の推定法で抢よその航走波の推定が可能となっ た。しかし、これら簡易式計算法で得られる情報量 には限界があり、また精度面で未だ十分であるとは 言い難い。今後航走波の影響に関する調查において、 より一層航走波の情報量の要求に対応し、高精度か
つ多くの情報量を提供する航走波の予測法が期待さ れる。特に、航走波の波紋や波内部の流体速度等の 正確な三次元情報量が得られると、航走波中の浮体 構造物の動摇特性および物体抗力の予測が可能とな ク、また岸壁での航走波の反射影響や越波、ビーチ エロージョンや水際の生息水生生物や植物群の生態 系への影響等の調査が可能となる。

このような背景から、著者は新しい航走波の推定 法として、数值流体力学的手法を応用した数值計算 を示した(4)。その結果、本手法が有益な航走波の情 報、特に正確な航走波の波紋を与えることを確認し た。この計算コードは本来、有限体積法に基づいた 船体周りの粘性流場の推定を主目的に開発されたも のである。

本研究は、この数値計算法に基づく航走波の計算 を行い、前報の二種類の簡易式航走波による計算結 果および実船を用いた実験結果との比較から、本計 算方法の評価を行うことである。その結果、数值計 算法が二種類の簡易式計算法と比較すると、得られ る航走波の情報量も多く、また精度面でもある程度 有益な結論が得られることがわかった。

\footnotetext{
* 正会員 長崎大学水産学部（T852-8521 長崎市文教町1-14）
} 


\section{2. 航走波の推定計算方法}

\section{1 機関馬力による推定法}

船舶の馬力から航走波の推定を行う方法であ る(5)。本手法は電卓で計算可能な簡易式であるため、 航走波の情報量は最大波高及びその波周期のみであ り、航走波の時系列等の詳細な情報は得られない。

\section{2 線形造波理論による推定法}

従来から船舶工学の分野で広く利用された線形造 波理論に基づいた推定法である。船速およびオフ セットデータが入力データであるが、簡易式計算法 であるため船型を簡単な幾何学的形状に近似し、そ れと等価な特異点分布の計算から航走波を得る ${ }^{(5)}$ 。

図 1 で示すように船首から任意距離R、航跡線か らの角度 $\Theta$ 位置における波面 $\xi(\mathrm{R}, \Theta)$ は次式で示 される。

$\xi(R, \Theta)=\int_{-\pi / 2}^{\pi / 2} S_{F}(\Theta) \sin \left\{K_{0} R \sec ^{2} \theta \cos (\Theta-\theta)\right\} d \theta$

ここに、 $\mathrm{K}_{0}=\mathrm{g} / \mathrm{V}^{2} 、 \mathrm{~S}_{\mathrm{F}}(\theta)$ は振幅関数で、特異点分 布から計算する。（1）式の積分は漸近展開で計算す る。

この方法では、簡易式であるため船舶から任意位 置における航走波の中で、船首波（縦波）の時系列 が求まるが、船尾後方の横波の計算はできない。航 走波の最大波高およびその周期は波時系列から読み 取って求める。

\section{3 数値計算による推定法}

Navier-Stokes方程式に基づいた船体周りの粘性 流場の計算は船体周囲の流場の厳密な推定や船体抵 抗係数の計算から船型改良等の船型設計に広く貢献 している(6) (10)。その中で有限体積法に基づいた船体 周りの高レイノルズ数流れの計算コードが児玉に よって開発された(11)(12)。このスキームでは擬似圧縮

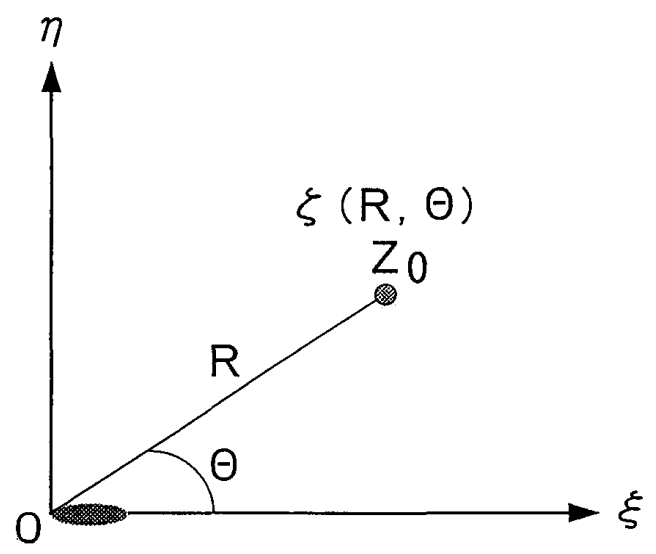

困 1 線形造波理論の座標系
性を導入し、流体の速度と圧力変数をまとめたべク トル量として取り扱い、非定常計算の収束值として 定常流を求めている。

擬似圧縮性を導入した保存型の三次元非圧縮性 Navier-Stokes方程式を次式で示す。

$$
\begin{aligned}
& \frac{\partial q}{\partial t}+\frac{\partial}{\partial x_{m}}\left(F_{m}^{*}+F_{v_{m}}\right)-a=0 \\
& (m=1,2,3 \quad \text { summation })
\end{aligned}
$$

ここに、

$$
\begin{gathered}
q=\left[\begin{array}{c}
u_{1} \\
u_{2} \\
u_{3} \\
p
\end{array}\right], F_{m}^{*}=\left[\begin{array}{c}
u_{1} u_{m}+p \delta_{1 m} \\
u_{2} u_{m}+p \delta_{2 m} \\
u_{3} u_{m}+p \delta_{3 m} \\
u_{m} \beta
\end{array}\right], \\
F_{v_{m}}=-\nu\left[\begin{array}{c}
\partial u_{1} / \partial x_{m}+\partial u_{m} / \partial x_{1} \\
\partial u_{2} / \partial x_{m}+\partial u_{m} / \partial x_{2} \\
\partial u_{3} / \partial x_{m}+\partial u_{m} / \partial x_{3} \\
0
\end{array}\right]
\end{gathered}
$$

$\left(\mathrm{x}_{1}, \mathrm{x}_{2}, \mathrm{x}_{3}\right)$ は船長Lで無次元化した静止Cartesian 座標である。ここに、 $\mathrm{x}_{1} 、 \mathrm{x}_{2} 、 \mathrm{x}_{3}$ はそれぞれ船首尾 方向で船尾に向けて正、左右舷方向で右舷に向けて 正、上下方向で鉛直上方に向けて正とし、 $\mathrm{u}_{1} 、 \mathrm{u}_{2} 、 \mathrm{u}_{3}$ は一様流の速度U⿻で無次元化した各方向の速度成 分、aは静止状態から加速しながら計算を開始する ので加速度項、 $\delta_{1 j}$ はクロネッカーのデル夕、擬似圧 縮を圧力項に導入するので $及$ 擬似圧縮性パラメー 夕で正の常数、 $\mathrm{p}=\mathrm{pr}+\mathrm{x}_{3} / \mathrm{Fn}^{2}$ は重力項を含んだ圧 力でprは流体内部の実圧力、FnはFroude数、 $\nu=\nu_{\mathrm{t}}+$ 1/RnでRnはReynolds数、 $\nu_{\mathrm{t}}$ はBaldwin-Lomax乱 流モデルから与えられる渦動粘性係数である。F粦の * 印は静止座標系上の定義を示す。

支配方程式の (1) 式を有限体積法で離散化する。た だし、自由表面の計算で自由表面適合座標を用いる ため、動座標系で一般的に成立する保存型の支配方 程式で取り扱う。（1）式を時間 $\mathrm{t} て ゙$ 変化するコント ロールボリュームV $(\mathrm{t})$ で積分すると、次式を得る。

$\int_{V(t)} \frac{\partial q}{\partial t} d V+\int_{V(t)} \frac{\partial}{\partial x_{m}}\left(F_{m}^{*}+F_{v_{m}}\right) d V$

$-\int_{V(t)} a d V=0 \quad(m=1,2,3 \quad$ summation $)$

(4) 式の第 1 項に一般化されたReynolds の輸送定 理、第 2 項にGaussの積分定理を用いると、支配方程 式は次式で表される。

$$
\begin{aligned}
& \frac{\partial}{\partial \tau} \int_{V(t)} q d V+\int_{S(t)}\left(F_{m}^{*}+F_{v m}-q \omega_{m}\right) n_{m} d S \\
& -\int_{V(t)} a d V=0
\end{aligned}
$$


ここに、 $\mathrm{S}(\mathrm{t})$ はV $(\mathrm{t})$ の境界面、 $\omega_{\mathrm{m}}$ はS $(\mathrm{t})$ の移動速 度、 $\mathrm{n}_{\mathrm{m}}$ はS $(\mathrm{t})$ の外向き単位法線べクトルである。 は動座標系における時間であり、動座標系 ( $\xi_{1}, \xi_{2}$, $\left.\xi_{3}, \tau\right)$ と物理空間のCaltesian座標の固定座標系 $\left(\mathrm{x}_{1}\right.$, $\left.\mathrm{x}_{2}, \mathrm{x}_{3}, \mathrm{t}\right)$ との関係は次式で表される。

$$
\begin{aligned}
& \xi_{1}=\xi_{1}\left(x_{1}, x_{2}, x_{3}, t\right), \xi_{2}=\xi_{2}\left(x_{1}, x_{2}, x_{3}, t\right), \\
& \xi_{3}=\xi_{3}\left(x_{1}, x_{2}, x_{3}, t\right), \tau=t
\end{aligned}
$$

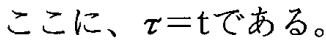

コントロールボリューム $\mathrm{V}(\mathrm{t})$ として格子セルを 用い、動座標系で(6)式の支配方程式を離散化する。 非粘性項の計算はFDS（Flux Difference Splitting） スキームに基づいた風上差分、粘性項は 2 次精度の 中心差分で計算する。時間微分にはpadè時間差分を 用いる。

$$
\frac{\partial}{\partial \tau}=\frac{1}{\Delta \tau} \frac{\Delta}{1+\theta \Delta}
$$

自由表面の計算において、動力学的境界条件は自 由表面をはさんだコントロールボリュームにおける 運動量の保存から導き、応力条件で表す。運動学的 境界条件は自由表面上にある流体粒子はその後も境 界上に留まるという条件であり、物体適合座標系に 変換し計算した。毎時間ステップで自由表面形状の 計算後、格子を再生成する。

本計算スキ一ムの特色は移流項にはMUSCL夕イ プの3 次風上差分を用いている。また、速度・圧力 変数はすべて格子セルの中心に置き、格子セルをコ ントロール・ボリュームとして用いることによって グローバルな保存性を満たしている。さらに、時間 差分には陰解法を、空間差分には近似因数分解法を 用いたI A Fスキームである。

2.1 おび2.2の計算方法が基礎式を簡略化あるい は経験式を用いた簡易的であるのに対し、本手法は Navier-Stokes方程式を各項の省略等がなく数值的 に丁寧に船体周りの流場及び自由表面波を解くた め、簡易的に対応し厳密的であると言える。したがっ て、本計算手法を以降「厳密な数值計算法」と称す。

本スキームは船体周りの粘性流場及び船体抵抗の 高精度な計算が主目的である。このため船体近傍で 細かい格子と大容量のメモリ一が要求されるので、 計算領域を船体周りの狭い範囲に制限する。しかし、 本研究の航走波では船体から離れた伝播波も計算す るため、船体表面から広範囲の計算領域に亘り密な 格子の生成は計算機容量及び計算時間の効率面から ほとんど不可能に近い。そこで、船体表面での最小 格子間隔を粗くし、格子数が減少した分だけ計算領
域を拡張、さらに船体近傍の粘性流場の計算精度を 下げ、波の計算を重視した方法で航走波の計算を 行った結果、波の計算精度に対する最小格子間隔の 依存性が少ないことがわかった ${ }^{(4)}$ 。したがって、本研 究では、計算機容量及び計算時間を考慮し、当面の 問題としてこの計算方法で行った。しかし、この数 年間の計算機メモリ一の技術開発が著しく、大容量 で安価なメモリーの増設が可能となり、またCPU計 算速度の飛躍的な改良が数年先に期待できるので、 今後高精度の粘性流場を含む航走波の計算が十分可 能であると考えられる。

入力データは、船型データの垂線間長、船幅およ び喫水、計算条件のFroude数及びReynolds数であ る。供試船の船型はWigleyモデルで近似した。これ は線形理論による推定法に用いたWigleyモデルに よく似た近似船型の計算結果との比較のためであ る。

困 2 は計算格子の一例である。格子はH-O夕イプ で、片舷のみ計算する。船体表面の最小格子間隔は 無次元間隔で0.001とした。

図 3 は航走波の計算を行った格子の垂直断面及び 静止水面を示す。本計算では、小型船舶が海洋構造 物等に接近して航行する場合を研究対象とするか ら、困の静止水面の計算領域内に被対象物が存在寸 ると仮定すればよい。計算領域の横幅は船長の約 4 倍程度であり、無次元計算領域は $-1.0 \leq \mathrm{x}_{1} \leq 9.0$ 、 $0.0 \leq \mathrm{x}_{2} \leq 4.0 、-4.0 \leq \mathrm{x}_{3} \leq$ 最大波の波頂高さであ る。格子数はi、j、k方向にそれぞれ234、77、39であ る。

計算は無次元時間間隔 $\Delta t=0.002$ で静止状態から 開始し、無次元時間 $T=22.0$ まで計算した。 Reynolds数は今後高精度の粘性流場を含む計算を 行うため $\mathrm{Re}=4.0 \times 10^{6}$ とした。

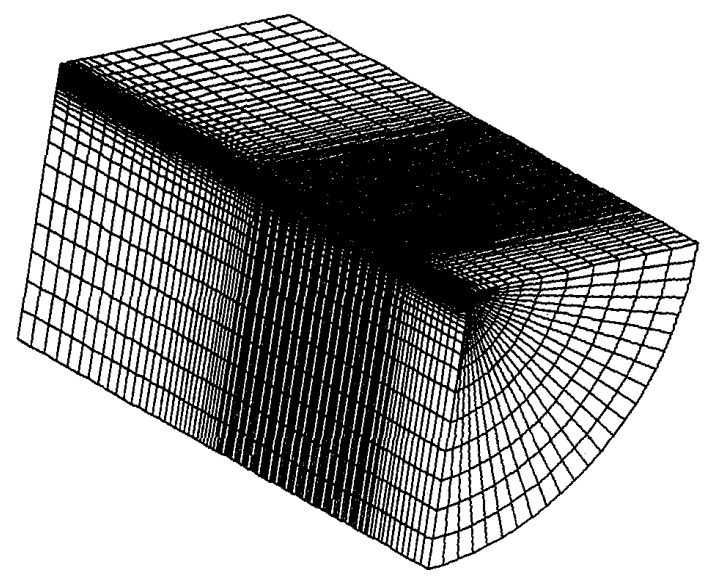

図 2 計算格子の生成 

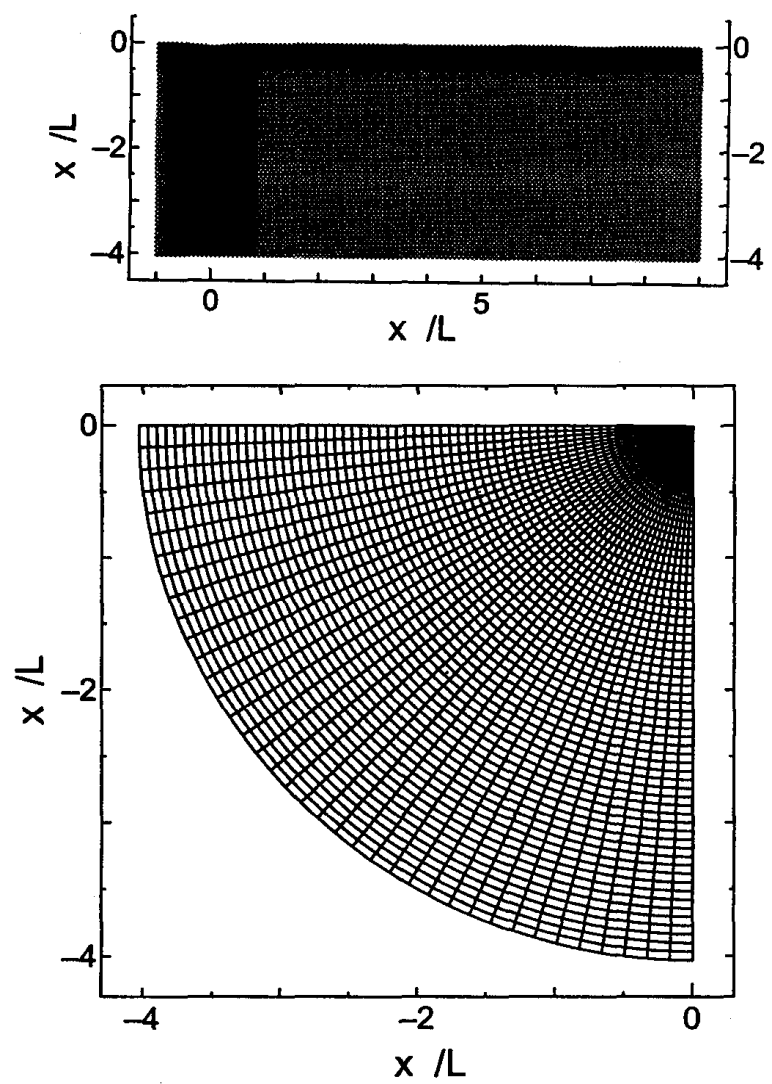

図 3 静止水面及び断面上の格子

\section{3、計算結果の比較}

航走波の推定を、従来の研究成果である二種類の 簡易式計算法および本研究で遵入した厳密な数值計 算法で行った。計算結果は、実海域で実船を用いた 航走波の計測結果とも比較検討し、今回新しく計算 した数值計算法の評価を行った。

実験に用いた船舶は、長崎大学水産学部所属の調 查船「鶴水」で、通常の排水量型小型船舶である。 図 4 は供試船、表 1 は船体の主要目を示す。この船 舶は長崎県沿岸海域の漁業及び環境調查などに使用 されている。実験海域は長崎県長崎湾の湾奥部で、 三方が陸地に囲まれた狭い海域である。実験当時風 はほとんどなく立地条件から吹送距離も短く風浪は 数 $\mathrm{cm}$ 程度、また外海からのうねりの進入もない静稳 海域であり、航走波の計測条件に最適な環境であっ た。実験海域の水深は深く、航走波の波長の推定か ら、深水波であり、浅水影響はないと考えられる。

困 5 は航走波の計測実験の概略を示す。実験は、 速力が一定で航行船舶からの距離が変化する場合で 行った。航走波は、岸壁から張り出した支柱先端に 取り付けた超音波式波高計で計測したので、一点で の波時系列しか得られない。

実験条件が速力一定で航行船舶からの距離が変化

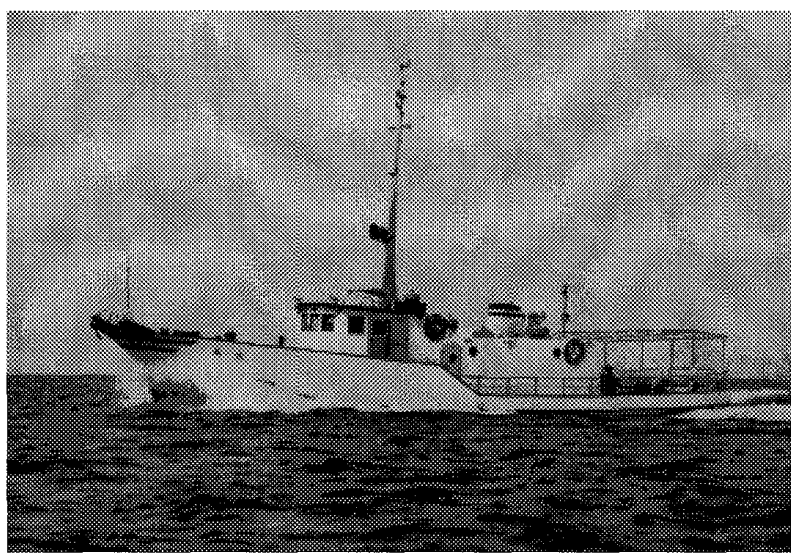

図 4 供試船「鶴水」

表 1 供試船の船体主要目

\begin{tabular}{|lr|r|}
\hline \multicolumn{2}{|c|}{ Item } & \multicolumn{2}{c|}{ KAKUSUI } \\
\hline $\mathrm{L}$ & (m) & 20.00 \\
\hline $\mathrm{L}_{\mathrm{on}}$ & (m) & 17.00 \\
\hline $\mathrm{B}$ & $(\mathrm{m})$ & 3.90 \\
\hline $\mathrm{D}$ & $(\mathrm{m})$ & 1.60 \\
\hline $\mathbf{d}_{\mathbf{m}}$ & (m) & 1.30 \\
\hline$\triangle$ & (ton) & 27.80 \\
\hline SHP $_{\mathrm{m}}$ & (hp) & 430.00 \\
\hline $\mathrm{V}_{\mathbf{k}}$ & (knot) & 10.00 \\
\hline
\end{tabular}

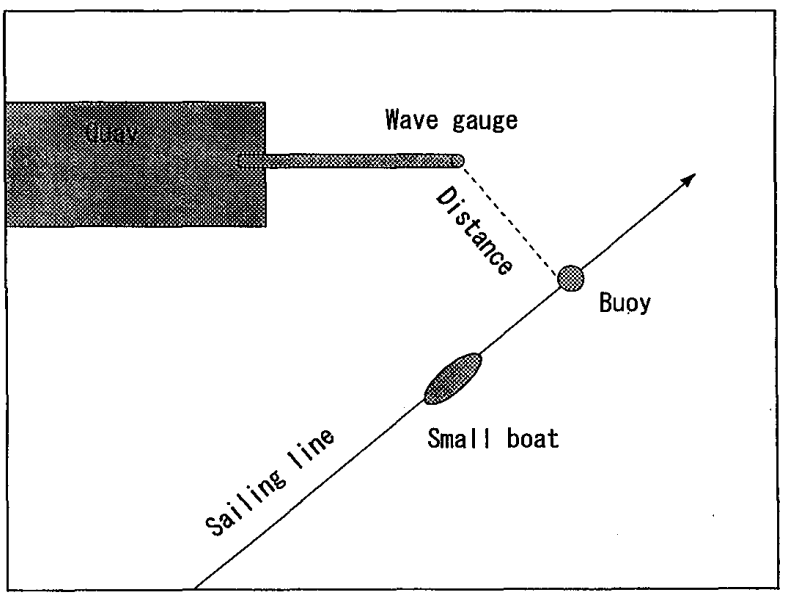

図 5 航走波の計測実験の概略

する場合の実験結果と計算結果との比較を行った。

図 6 は速力が一定 $(10.3 \mathrm{k}$ 't $)$ で距離が変化する場 合の実験と計算結果の比較を示す。距離は船長Lで、 最大波高と周期は重力および速力でそれぞれ無次元 化している。図中の黒丸印は実験結果、Cal.-1は馬力 による推定結果、Cal.-2は線形造波理論による推定 結果および白抜き三角印は数値計算による推定結果 である。

波高に関し、䒠験結果に多少ばらつきが見られる。 簡易式計算法のCal.-1とCal.-2の波高の比較では、 短い距離でCal.-1は極端に増加し現実的でない。距 

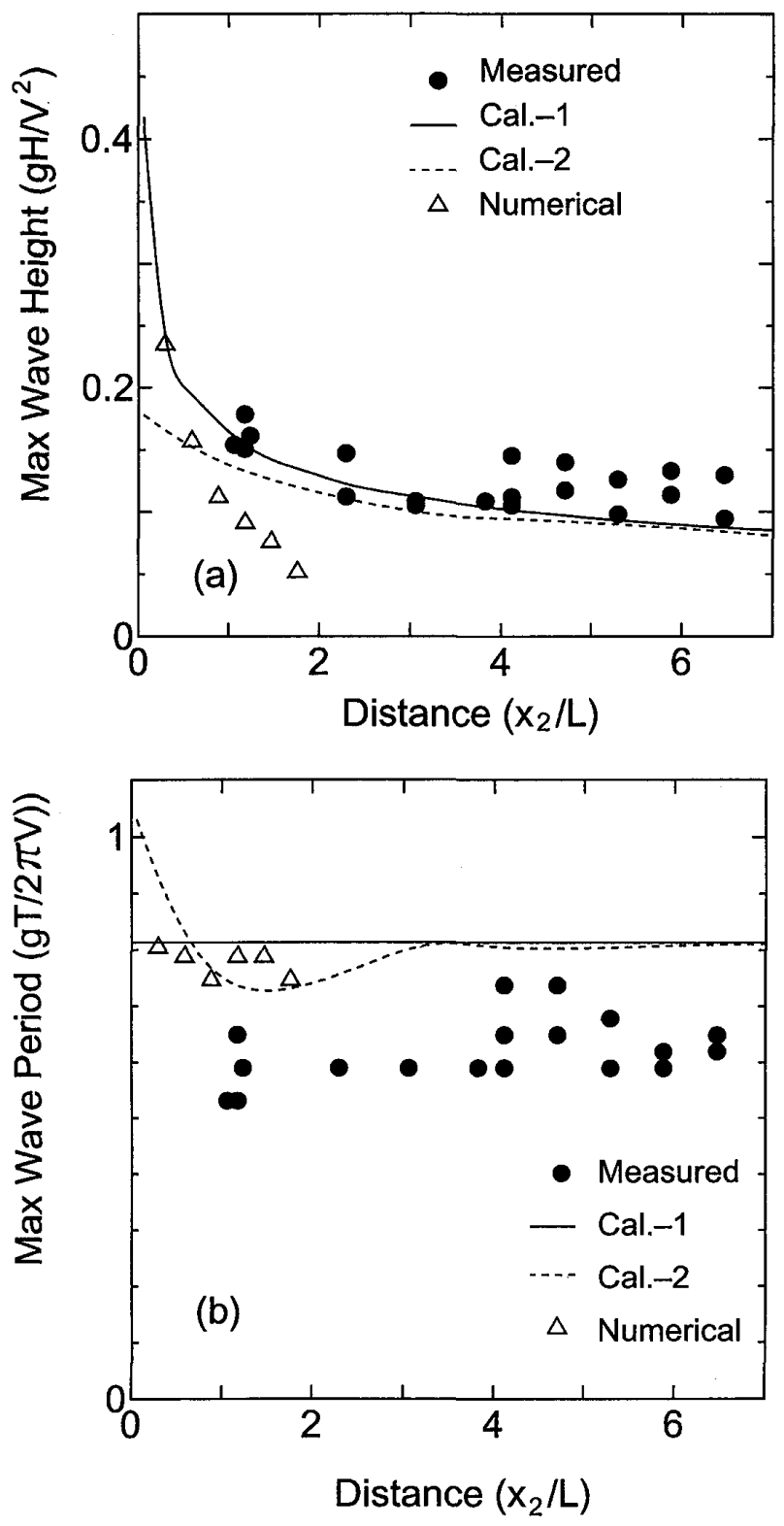

図 6 船速が一定距離が変化する場合

離が長くなるとCal.-1とCal.-2の結果はよく一致し ている。全体に、両簡易式計算結果と実験結果はおお よそ一致するので、簡易式推定法による航走波の計 算は十分可能であると言える。他方、数值計算結果 は、短い距離では簡易式計算結果とよく一致してい るが、距離が長くなると急激に波高が減衰し、波高 の予測は十分でない。これは数值粘性等に起因し、 波が十分発達しなかったものと考えられるが、詳細 は検討中である。

波周期に関し、実験周期のばらつきが大きい。簡 易式計算法の結果では、船速が一定であるため、Cal. -1の無次元周期は一定となる。Cal.-2の計算結果は 短い距離でCal.-1の結果と差が見られるが、距離が 長くなると両者はほぼ一致する。実験值は簡易式計 算結果より小さく、一致しない。これは実船の場合、

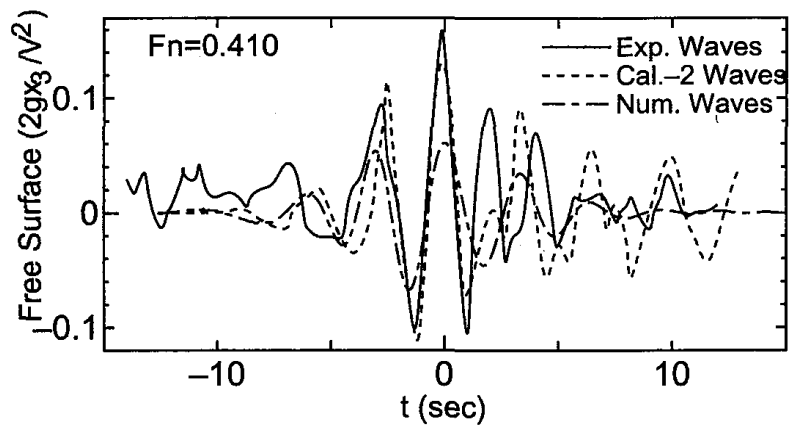

困 7 航走波の時系列の比較

特に船首で生成された航走波が船首周りで砕波後、 伝播の途中で、再度波崩れ等のため、波の变形が起 こるのに対し、計算波では砕波現象はなく理論通り に伝播すること等に起因することが予想される。数 值計算法の波周期はCal.-1㧍よびCal.-2の計算結果 に抄よそ一致している。これらの結果から 3 種類の 計算周期はおよそ同じになる。

図 7 は実験波、Cal.-2および数值計算による計算 波の時系列を示す。Cal.-1の計算法では波の時系列 が得られない。船舶からの無次元距離は $\mathrm{x}_{2} / \mathrm{L}=1.0$ である。縦軸は重力の加速度および船速の 2 乗で無 次元化し、横軸は時間 $(\mathrm{s})$ を示す。Froude数はFn= 0.410 、速力は $10.3 \mathrm{k}$ 'tである。Cal.-2および数值計算 波の位相差が小さく両者の波形はよく似ているが、 図6の通り数值計算波の波高が低いため、特に、波 の谷部より、山の部分で両者の水面変位に差が見ら れる。実験波と計算波の波形の比較では、図 6 で示 した通り周期の相違により、波の位相が一致しない。 また、実験波形は最大波の部分でCal.-2の計算波形 とほぼ一致しているが、数值計算波の波形とは水面 変位に差が見られる。以上の結果、数值計算波の距 離に対する波高の減衰が著しく、図 5 でも示した通 り波高に関してCal.-2の計算法の方が優れていると 思われる。波高減衰に対する対策を目下検討中であ る。波の位相に関してCal.-2と数值計算法の結果に 差が見られないので、数值計算法による波の時系列 の計算は良好であると考えられる。

図 8 は数値計算による波紋を示す。従来の二種類 の簡易式計算法では波紋のような三次元情報を得る ことは出来ない。Froude数はFn=0.410である。等 波高線間隔は無次元波高で $x_{3} / \mathrm{L}=0.0005$ 毎に描い ている。実船での航走波の波紋計測は難しく、計測 実験例がないので、実験との検証はできない。しか し、航走波特有の船首尾から発生する縦波および、 船尾後方の横波が十分再現され、Kelvin波の波紋に よく似ている。また、著者による参考文献 4 )で、 


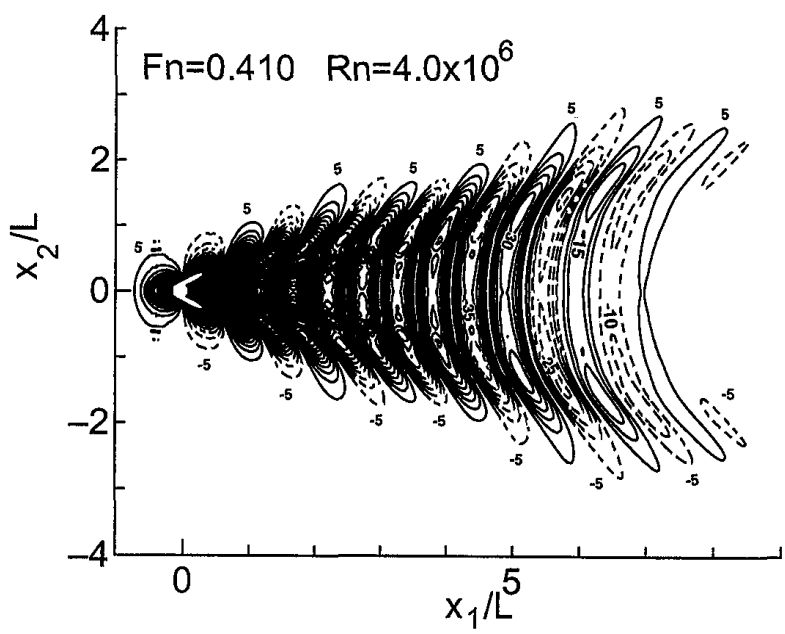

困 8 数值計算による波紋 $\left(\mathrm{x}_{3} / \mathrm{L} \times 10^{4}\right)$

Wigley船型モデルを用いた格子依存性に関する検 証において、計算と曳航水槽実験による波紋の比較 および異なる格子間隔の格子による計算結果の比較 から、これらの波紋に任とんど差が見られなかった ことを確認した。以上の結果、波高の低下を除き、 航走波の三次元波形である波紋の予測が、高精度に できると考えられる。

\section{4. 結 論}

厳密な数值計算法で小型船舶による航走波の推定 を行った。実船による航走波の計測実験結果および 従来からの二種類の簡易式計算法による計算結果と の比較から、本数值計算法の特性について調査した。 実験に用いた実船は通常の排水量型小型船舶であ る。本研究で得た主な結果は次の通りである。

1）二種類の簡易式計算法である、船舶の馬力に よる推定法 (Cal.-1) 及び線形造波理論による 推定法 (Cal.-2) で得た航走波の計算波高は実 験波高とよく一致するから、両推定法で波高の 予測が十分可能である。しかし、波周期に関し、 両計算法による周期は実験周期より大きくな ク、一致しない。

2）厳密な計算法である数值計算法では、航走船 舶から伝播した航走波の波高減衰が著しく実 験波高より小さくなり、また二種類の簡易式計 算結果よりも小さい。波周期に関して、数值計 算結果は二種類の簡易式推定法による計算結 果とおよそ一致する。

3) Cal.-2および数值計算による航走波の時系 列の推定では、Cal.-2による波形の方が、波高 に関し垁験波とより一致する。数值計算による 波形は波高が小さいが、Cal.-2の波形とよく似 ている。両計算波および実験波の波形を比較す
ると、波周期の差から波の位相差が見られる。

4) 数值計算法しか計算が可能でない航走波の 波紋のパターンから、航走波特有の縦波および 横波の高度な推定計算が可能である。

本研究の結果、以下の事柄を今後検討する予定で ある。

a）数值計算法において、波高減衰の原因追究お よびその対策

b）最近応用されている境界要素法による航走 波の推定計算の構築および比較検討

c）ビー千等の浅水域に伝播した航走波の変形 過程抢よび海岸浸食等の予測

d）岸壁等の遮蔽物による航走波の反射影響

著者は、粘性を考慮した航走波の高度な推定が可 能な計算手法の開発を行い、ポテンシャル理論では 解明できない複雑な現象の追求を行なう所存であ る。

\section{参 考 文 献}

（1）塩谷茂明·藤冨信之·斎藤勝彦·石田廣史・山里重 将: 三種類の小型実船による航走波の特性, 水 産工学, Vol. 33, No.2, pp. 123-134 (1996).

(2) S. Shiotani, N. Fujitomi, K. Saito and H. Ishida : Measurements and Simplified Estimation Methods of Ship Waves due to Small Vessel, Proceedings of Techno-Ocean'96 International Symposium, pp. 663-668 (1996).

（3）塩谷茂明・藤富信之・斎藤勝彦：実海域におけ る滑走艇による航走波の特性について，日本航 海学会論文集，第98号，pp. 17-26（1998）.

（4）塩谷茂明：有限体積法を用いた数值計算による 航走波の推定について, 水産工学, Vol. 38, No. 1 , pp. 43-51 (2001).

（5）日本海難防止協会：海上交通安全に関する基礎 的事項の調查研究, 一航行船舶の航走波が小型 船舶に及ぼす影響の研究一, 海難防止の調查研 究事業報告書, 完了報告書, p.83 (1971).

(6) Miyata, H. Nishimura, S. and Masuko, A., Finite Differencing Simulation Nonlinear Waves Generated by Ships of Arbitrary Three-Dimensional Configuration, Journal of Computational Physics, Vol.60, pp. 371-394 (1985).

(7) Hino, T., Computation of a Free surface Flow around an Advancing Ship by the Navier -Stokes Equations, Proceedings of 5th International Conference on Numerical Ship Hydrodynamics, Hiroshima, Japan, pp. 
103-117 (1989).

(8) Kwag, S. Y. and Mori, K., Numerical Simulation of High Reynolds Number Flows with Free Surface, Transactions of The West -Japan Society of Naval Architects, Vol. 80, pp. 13-22 (1990).

（9）渡辺修・朱明・宮田秀明：有限体積法による自 由表面を含む船体まわりの粘性流のシミュレー ション, 日本造船学会論文集, 第171号, pp. 27-39 (1992).

(10) Kawamura, T. and Miyata, H. : Simulation of Non-linear Ship Flows by Density Function Method, Journal of The Society of Naval Architects of Japan, Vol. 176, pp. 1-10 (1994).

(11) Kodama, Y., Computation of Ship's Resistance Using an NS Solver with Global Conservation, Journal of The Society of Naval Architects of Japan, Vol. 172, pp. 147-155 (1994).

(12) Shiotani S. and Kodama Y. : Numerical Simulation of Viscous Flow with Free-Surface around a Ship Model, International Conference on Computational Engineering Science, Springer, pp. 838-843 (1995).

\section{質 疑 応 答}

水井真治 (広島商船高等専門学校)：1点だけ質問さ せていただきます。数值計算波と実験波の位相が 部分的に一致しない理由についてご教授いただけ ますか。

塩谷茂明：御討論有り難うございます。実験波は実 海域で実施しましたので、水槽実験と比較します と計測がかなり難しく、誤差等の要因が混在して いると考えます。また、数值計算の場合、船型を Wigleyモデルで近似したこと等により、実船の船 型との若干の相違も原因するかと思います。これ らが複雑に関係しているのではないかと考えてい ます。

南 清和(東京商船大学)：実船実験をされておられ ますが、実施上において外乱の影響をどのように 考慮されたのか、ご教授願います。

塩谷茂明：御討論有り難うございます。最も顕著な 外乱は航走波以外の風波およびうねりと思います ので、これついて解答します。本文にも示しまし たが、実験現場が湾奥部であり、うねりの進入は ありません。また時期は夏季であり、ほとんど無 風状態で、吹送距離も短く、風波は数 $\mathrm{cm} の$ オーダ でした。従いまして、航走波の波高と比較します と: 数\%程度でしたので、微小であると言うこと で無視し、特別な考慮はしていません。 